\title{
Growth Dynamics of Araucaria after Management Interventions in Natural Forest
}

\author{
Régis Villanova Longhi ${ }^{1}$, Paulo Renato Schneider ${ }^{1}$, Solon Jonas Longhi², \\ Gabriel Paes Marangon ${ }^{3}$, Emanuel Arnoni Costa ${ }^{1}$ \\ ${ }^{1}$ Departamento de Ciências Florestais, Universidade Federal de Santa Maria - UFSM, Santa Maria/RS, Brazil \\ ${ }^{2}$ Universidade Tecnológica Federal do Paraná - UTFPR, Dois Vizinhos/PR, Brazil \\ ${ }^{3}$ Centro de Ciências Agrárias, Universidade Federal de Alagoas - UFAL, Rio Largo/AL, Brazil
}

\begin{abstract}
The objective of this study was to evaluate the effect of selective logging on the growth dynamics of Araucaria angustifolia in a natural forest of Rio Grande do Sul state, Brazil. Treatments were based on percentage reduction of the basal area per DBH class, namely, T0 (control) $=0 \%$; T1 $($ light selective logging) $=$ reduction of $20-30 \%$; T2 $($ moderate selective logging $)=$ reduction of $40-50 \%$. Data were obtained prior to the management interventions and four, eight and 13 years after selective logging. Changes between treatments were assessed using the following parameters: absolute density, absolute dominance, importance value index, and growth rates. Results show that population reduction and canopy opening provided greater recruitment and higher growth rates for araucaria in the management treatments (T1 and T2) compared with those of the control treatment (T0). These results reinforce that management practices are necessary for the continuous development of araucaria in this forest formation.
\end{abstract}

Keywords: increment, selective logging, mixed forest. 


\section{INTRODUCTION}

Araucaria angustifolia (Bertol.) Kuntze (Brazilian pine; araucaria) is a tree species characteristic of Mixed Ombrophilous Forests (MOF), also known as Forests with Araucaria (IBGE, 2012). In Brazil, this formation occurs in the southern states located below the Tropic of Capricorn, having a humid subtropical climate, within latitudes 19 and $31^{\circ} \mathrm{S}$ and longitudes 41 and $54^{\circ} \mathrm{W}$ (Cabral \& Cesco, 2008), 500 to $1200 \mathrm{~m}$ above sea level (Guerra et al., 2002).

It was estimated that there was approximately 25 million hectares of Forest with Araucaria at the beginning of the 20th century (Ribeiro et al., 2009). During the wood cycle however, in the 1950s and 60s, there was intense exploitation of timber species such as Araucaria (Araucaria angustifolia (Bertol.) Kuntze) and Brazilian walnut (Imbuia) (Ocotea porosa (Mez) L.Barroso), and non-timber species such as Xaxim (Dicksonia sellowiana Hook.) (Higuchi et al., 2012). This reduced the Forests with Araucaria to $12.6 \%$ of their original extension (Ribeiro et al., 2009). In the state of Rio Grande do Sul, of the $25.0 \%$ of the previously existing original area (Carvalho, 1994), only $10.6 \%$ is still covered with MOFs (Cordeiro \& Hasenack, 2009), and these are at initial, intermediate and advanced stages of succession, highly decharacterized compared with their original structure.

As a result of these intense exploitation pressures in the past, Araucaria angustifolia was included in the vulnerable category in the official list of Brazilian flora species threatened with extinction (IBAMA, 1992), and more recently in the IUCN Red List of Threatened Species (Thomas, 2013) as critically endangered. Felling of araucaria in natural forests is currently prohibited by law. However, history shows that restrictions on the use of a natural resource are rarely observed by the general population, especially when the resource is a raw material or source of income. In these cases, protection through prohibition means devaluation of the good, which quite often leads to a loss of interest in its conservation (Nutto, 2001).

In addition, what has been observed in the understory of Forests with Araucaria at advanced stages of development and with high density of trees is a high mortality rate combined with low natural regeneration of this species, leading to uncertainties in terms of its capacity for regenerative and continuous development in the forest. Some studies have reported low regeneration capacity under developed forest (Soares, 1979; Narvaes et al., 2005; Souza et al., 2008; Beckert et al., 2014).

According to Rosot (2007), an effective way to revert the trend of fragmentation and degradation of Forests with Araucaria is the adoption of multiple-use forest management, which requires research to be conducted into Araucaria Forest management that goes beyond a merely academic focus and formulates an effective technical-scientific basis capable of creating legal instruments to regulate the use of forest resources, as well as to underpin policy to encourage these measures.

According to Smith (1986), one of the purposes of forest management is to maximize sunlight availability for natural regeneration and for commercial species remaining in the forest, aiming to increase the growth rate of trees and, consequently, have shorter logging cycles. However, in the domain of Mixed Ombrophilous Forest, there is a lack of studies on the behavior of remaining vegetation after management controlled interventions, so that the benefits of this practice for the restructuring of altered forests and/or sustainable forest use could actually be confirmed.

In this context, the objective of this study was to evaluate the growth dynamics of $A$. angustifolia after 13 years of application of different intensities of selective logging in a Mixed Ombrophilous Forest located in the upper slope of northeastern Rio Grande do Sul state, Brazil. To this end, two hypotheses were made: i) Selective logging of leafy species of high density and dominance benefit the recruitment of $A$. angustifolia in the forest; ii) Controlled reductions of population density in the forest, through selective logging, increase A. angustifolia growth rates compared with those of unexploited areas.

\section{MATERIAL AND METHODS}

This study was conducted in the "Fazenda Tupi", which belongs to "Paludo Agropecuária S.A., a company of the VIPAL group, located in the municipality of Nova Prata, Rio Grande do Sul state (28 $40^{\prime}$ and $28^{\circ} 43^{\prime} \mathrm{S}$; $51^{\circ} 38^{\prime}$ and $\left.51^{\circ} 36^{\prime} \mathrm{W}\right)$. The total area of the farm is 962 ha, with 784 ha of Mixed Ombrophilous Forest, according to IBGE (2012). This area presents a 
history of intensive exploitation, which started in the 1970s culminating in indiscriminate exploitation of Araucaria angustifolia in the mid 80s, when most of the larger individuals present on the property were logged. This exploitation modified the structure of the forest fragment both through the intensive logging of the araucarias as well as through the damage caused to the remaining trees. Recently, in a forest inventory with a large sampling effort (7.1 ha) conducted on this farm, Callegaro et al. (2016) observed mean density for Araucaria angustifolia of 14.5 ind.ha $^{-1}$, and mean values for density, basal area, height, and diameter for the forest in general of 600 ind.ha ${ }^{-1}, 32.08 \mathrm{~m}^{2} \cdot \mathrm{ha}^{-1}$, $13.9 \mathrm{~m}$, and $22.2 \mathrm{~cm}$, respectively; which characterizes this vegetation as secondary, at an advanced stage of natural regeneration, according to the resolution no. 33/94 by CONAMA (Brasil, 2012).

The relief of the region is predominantly undulating, with occurrence of Nitosols and Neosols (Streck et al., 2008). According to the Köppen classification, climate in the study area is Cfa, humid subtropical with hot summers (Alvares et al., 2013), mean annual temperature of $17.0^{\circ} \mathrm{C}$, and rainfall distributed throughout all months of the year, with annual precipitation of approximately $1900 \mathrm{~mm}$.

In 2001, a management experiment was initiated at the MOF of "Fazenda Tupi" aiming to test different selective logging intensities compared with a silvicultural treatment applied to the forest. Six sample units of $50 \mathrm{~m} \times 100 \mathrm{~m}$ (0.5 ha) were established, divided into plots of $10 \mathrm{~m} \times 10 \mathrm{~m}$ for spatial control of the individuals, comprising a total sample area of $3.0 \mathrm{ha}$. The units were spaced approximately $30 \mathrm{~m}$ from each other and were at least $100 \mathrm{~m}$ distant from the forest edge, thus avoiding border effects. At that time, all trees with circumference at breast height $\geq 31.4 \mathrm{~cm}(\mathrm{DBH} \geq 10.0 \mathrm{~cm})$ present in each management unit were identified and numbered using aluminum plates; a $2 \mathrm{~cm}$-wide yellow strip was also painted at measurement height $(1.30 \mathrm{~m})$ to avoid errors in subsequent measurements.

In 2002, the interventions were designed and conducted in the study by Borsoi (2004). They consisted of reducing the adjusted frequency distribution curve per DBH class at different percentage levels of basal area. One of the following treatments was applied to each of the sample units: T0 - control: unlogged area; $\mathrm{T} 1$ - light selective logging: reduction of the adjusted frequency distribution curve with logging of approximately $20-30 \%$ of the total basal area per DBH class; T2 - moderate selective logging: reduction of the adjusted frequency distribution curve with logging of approximately $30-40 \%$ of the total basal area per DBH class. The frequencies were adjusted based on the model by Meyer (1952), considering diameter classes with amplitude of $10.0 \mathrm{~cm}$.

At the time of the selective logging interventions, trees of all diametric classes were felled, covering a range of 10.0 to $80.0 \mathrm{~cm}$ in diameter. According to each selective logging intensity, preference was given to hardwood species with higher absolute density (especially Matayba elaeagnoides) and to defective, dead and damaged individuals. This logging preference aimed, for the next intervention, to obtain individuals with regular stems, well distributed canopies and, consequently, a more productive forest with regular distribution of species. Felling of trees was semi-mechanized, with cleaning of lianas off the selected ones, and logging was performed so that the felling of the trees affected the minimum number of individuals possible, both adults or from natural regeneration, as highlighted by Borsoi (2004). It is worth noting that, in this first management intervention, A. angustifolia trees were not felled due to the logging prohibition in force at the time.

The data used in this study was obtained from the inventory conducted prior to the management interventions (2001) and at three monitoring times, namely, the inventories conducted in 2006, 2010, and 2015, after four, eight and 13 years of selective logging, respectively. Changes in the horizontal structure of each management treatment were evaluated prior to the selective logging intervention and four and thirteen years after the application of forest management. To this end, traditionally used phytosociological parameters were estimated: absolute density, absolute dominance, and importance value index (Mueller-Dombois \& Ellenberg, 1974).

The growth rates of $A$. angustifolia between the different management treatments, at each time of assessment, were represented by the relative annual diameter increment (ADI\%) instead of the absolute increment, considering that the capacity of a tree to gain increment in diameter is related to its initial diameter. For comparison between the growth rates, a completely randomized design (CRD) with a different number 
of observations (unbalanced) was used, considering the trees present in each selective logging intensity as repetitions. Data resulting from the ADI\% were submitted to analysis of variance (ANOVA) and means were discriminated by the Tukey-Kramer test at the significance level of $\alpha=0.05$. To ensure the application of significance tests based on the $F$ distribution, tests of normality and homogeneity of variances were applied for the response variable - ADI\%. To this end, the Levene test was used to verify homogeneity, whereas the Shapiro-Wilk test was applied for normality. In order to comply with the assumptions, the method proposed by Box \& Cox (1964) was used to stabilize the variance by means of a lambda power $(\lambda)$ estimated by maximum likelihood.

\section{RESULTS AND DISCUSSION}

Table 1 shows the participation of $A$. angustifolia in the horizontal structure of the forest fragment in each management treatment and for each measurement time, considering the 10 species of highest importance value (IV\%) 13 years after the interventions. In all treatments, Matayba elaeagnoides was the species with the highest IV\%, confirming the current stage of secondary development of the forest, not presenting A. angustifolia as the most important species of the canopy, which was cited by many authors, including Reitz et al. (1983) and Kanieski et al. (2010), as a species of constant and dominant presence in the domains of the Mixed Ombrophilous Forest.

The forest showed good restructuring capacity in its parameters for the selective logging treatments (T1 and T2), considering that the logging preference for individuals of high absolute density and low commercial interest at the time of the interventions (M. elaeagnoides in the present study) resulted in a positive change in the analyzed phytosociological parameters, which increased the participation of species of greater economic value/importance, such as A. angustifolia. Prior to the management interventions (2001), this species occupied the fourth position in the ranking of importance value in the light selective logging treatment $(I V I \%=4.96 \%)$, the third position in the ranking in the moderate selective logging treatment (IVI\% $=5.91 \%)$, and the sixth position in the control treatment $(\mathrm{IVI} \%=6.60 \%)$. Thirteen years after the interventions, greater increase in the importance value index for this species was observed in the selective logging treatments (T1 and $\mathrm{T} 2$ ) compared with the control treatment (T0). This index showed values of 7.98\% (third position in the IVI\% ranking) and 8.73\% (second position in the IVI\% ranking) for the light (T1) and moderate (T2) selective logging treatments, respectively, with both values higher than those for the control treatment (T0), which was $7.20 \%$.

Despite the intense logging to which M. elaeagnoides was submitted due to its presenting the highest absolute density and dominance values in the area at the time of the interventions, it was still the most important species in the forest thirteen years after the selective logging interventions in the analysis of both management treatments. However, decreases in the importance value indices of $27.50 \%($ IVI\% $=23.53 \%)$ for the light selective logging treatment (T1) and of $32.1 \%$ (IVI\% $=29.20 \%)$ for the moderate selective logging treatment (T2) were observed compared with those found prior to the management interventions $(\mathrm{IVI} \%=34.66 \%$ in $\mathrm{T} 1$ and $\mathrm{IVI} \%=40.29 \%$ in $\mathrm{T} 2)$.

Analysis of the behavior for the absolute density and absolute dominance variables per hectare showed that, among the selective logging treatments, only T1 (light selective logging) was able to recover the initial density and basal area thirteen years after the management interventions, presenting absolute values of 684 ind.ha $^{-1}$ and $29.59 \mathrm{~m}^{2}$.ha ${ }^{-1}$, respectively. Additionally, these values correspond to increases of 44 ind.ha $^{-1}$ and $2.80 \mathrm{~m}^{2} \cdot \mathrm{ha}^{-1}$ compared with those observed prior to the interventions.

Regarding the control treatment (T0), a decrease of 71 ind.ha ${ }^{-1}$ was observed in absolute density, with an increase of only $1.39 \mathrm{~m}^{2} \cdot \mathrm{ha}^{-1}$ in the basal area, compared with the first measures taken in 2001. This observation shows the high degree of competition in the forest, considering that the high density of trees reflects the lower availability of resources (sunlight, nutrients, etc.), mainly in the lower strata of the forest, thus leading to low growth rates and high natural mortality rates of individuals.

Highlighting A. angustifolia, Table 2 shows the changes that occurred over time in the absolute density, mean diameter, mean height and basal area variables in each management treatment applied in the forest. Prior to the interventions (2001), the absolute density of $A$. angustifolia was similar between the 
treatments, presenting the following values: 22 ind. ha ${ }^{-1}$ for T0 (control), 17 ind.ha ${ }^{-1}$ for T1 (light selective logging), and 23 ind.ha $^{-1}$ for T2 (moderate selective logging). Thirteen years after the forest management, it was possible to verify that the selective logging interventions, in addition to stimulating recruitment, caused no mortality of individuals during this period.

Total recruitment was 24 ind.ha ${ }^{-1}$ in $\mathrm{T} 1$ and 7 ind.ha $^{-1}$ in T2. Of these, greater recruitment was observed between eight and 13 years after the selective

Table 1. Phytosociological parameters of the 10 species of highest Importance Value Index (IVI\%) in each management treatment and time of measurement.

\begin{tabular}{|c|c|c|c|c|c|c|c|c|c|c|c|c|}
\hline \multirow{2}{*}{ Species } & \multicolumn{4}{|c|}{2001 ( -1 year $)$} & \multicolumn{4}{|c|}{$2006(+4$ years $)$} & \multicolumn{4}{|c|}{2015 ( +13 years) } \\
\hline & $\mathbf{P}$ & AD & ADo & IVI\% & $\mathbf{P}$ & AD & ADo & IVI\% & $\mathbf{P}$ & AD & ADo & IVI\% \\
\hline \multicolumn{13}{|l|}{ T0 - Control (unlogged) } \\
\hline Matayba elaeagnoides & 1 & 122 & 4.48 & 13.78 & 1 & 112 & 4.52 & 14.22 & 1 & 107 & 4.85 & 14.19 \\
\hline Zanthoxylum kleinii & 2 & 67 & 4.01 & 9.95 & 2 & 64 & 4.24 & 10.57 & 2 & 60 & 4.65 & 10.38 \\
\hline Myrciaria floribunda & 4 & 88 & 1.58 & 8.18 & 3 & 88 & 1.66 & 8.84 & 3 & 80 & 1.71 & 8.52 \\
\hline Araucaria angustifolia & 6 & 22 & 4.35 & 6.60 & 7 & 21 & 4.56 & 7.01 & 4 & 21 & 5.02 & 7.20 \\
\hline Erythroxylum deciduum & 3 & 72 & 2.16 & 8.29 & 4 & 61 & 2.09 & 7.98 & 5 & 50 & 1.95 & 7.05 \\
\hline Lithraea brasiliensis & 5 & 55 & 3.31 & 7.66 & 5 & 47 & 3.23 & 7.44 & 6 & 40 & 3.14 & 6.69 \\
\hline Blepharocalyx salicifolius & 7 & 40 & 1.56 & 5.31 & 8 & 37 & 1.63 & 5.52 & 7 & 35 & 1.86 & 5.50 \\
\hline Cupania vernalis & 9 & 39 & 1.06 & 4.37 & 9 & 36 & 1.06 & 4.52 & 8 & 40 & 1.25 & 5.07 \\
\hline Campomanesia xanthocarpa & 10 & 34 & 0.67 & 3.69 & 11 & 36 & 0.76 & 4.26 & 9 & 40 & 0.90 & 4.64 \\
\hline Myrcia obtecta & 8 & 46 & 1.14 & 4.94 & 10 & 38 & 1.01 & 4.43 & 10 & 37 & 1.04 & 4.44 \\
\hline Other species & & 201 & 7.48 & 27.23 & & 178 & 6.18 & 25.21 & & 184 & 6.82 & 26.32 \\
\hline TOTAL & & 786 & 31.80 & 100 & & 718 & 30.93 & 100 & & 694 & 33.19 & 100 \\
\hline \multicolumn{13}{|c|}{ T1 - Light selective logging (reduction of $20-30 \%$ of basal area) } \\
\hline Matayba elaeagnoides & 1 & 271 & 10.59 & 34.66 & 1 & 171 & 6.69 & 25.86 & 1 & 183 & 7.88 & 23.53 \\
\hline Cupania vernalis & 2 & 70 & 1.75 & 9.75 & 2 & 71 & 1.92 & 11.02 & 2 & 88 & 2.60 & 11.18 \\
\hline Araucaria angustifolia & 4 & 17 & 2.12 & 4.96 & 3 & 24 & 2.59 & 6.76 & 3 & 41 & 3.57 & 7.98 \\
\hline Myrciaria floribunda & 7 & 26 & 0.40 & 3.80 & 5 & 33 & 0.51 & 5.02 & 4 & 41 & 0.71 & 5.43 \\
\hline Luehea divaricata & 6 & 14 & 1.69 & 3.82 & 6 & 16 & 1.87 & 4.74 & 5 & 21 & 2.20 & 4.75 \\
\hline Casearia decandra & 3 & 37 & 0.74 & 5.43 & 4 & 33 & 0.63 & 5.10 & 6 & 34 & 0.69 & 4.69 \\
\hline Ilex paraguariensis & 8 & 15 & 1.31 & 3.66 & 7 & 17 & 1.28 & 4.22 & 7 & 26 & 1.60 & 4.60 \\
\hline Ocotea pulchella & 9 & 10 & 1.24 & 2.95 & 8 & 10 & 1.35 & 3.39 & 8 & 10 & 1.53 & 2.99 \\
\hline Solanum mauritianum & 13 & 15 & 0.21 & 2.11 & 11 & 19 & 0.35 & 2.67 & 9 & 23 & 0.60 & 2.93 \\
\hline Campomanesia xanthocarpa & 12 & 14 & 0.31 & 2.18 & 13 & 15 & 0.36 & 2.52 & 10 & 19 & 0.49 & 2.68 \\
\hline Other species & & 143 & 6.26 & 26.68 & & 148 & 5.81 & 28.70 & & 181 & 7.15 & 29.24 \\
\hline TOTAL & & 638 & 26.62 & 100 & & 557 & 23.38 & 100 & & 667 & 29.02 & 100 \\
\hline \multicolumn{13}{|c|}{ T2 - Moderate selective logging (reduction of $40-50 \%$ of basal area) } \\
\hline Matayba elaeagnoides & 1 & 298 & 14.22 & 40.29 & 1 & 165 & 7.95 & 34.05 & 1 & 164 & 8.87 & 29.20 \\
\hline Araucaria angustifolia & 3 & 23 & 2.80 & 5.91 & 2 & 23 & 3.19 & 8.63 & 2 & 30 & 3.84 & 8.73 \\
\hline Myrciaria floribunda & 5 & 35 & 0.53 & 4.89 & 4 & 37 & 0.53 & 6.70 & 3 & 56 & 0.84 & 7.74 \\
\hline Erythroxylum deciduum & 2 & 52 & 2.09 & 7.75 & 3 & 37 & 1.61 & 8.05 & 4 & 32 & 1.55 & 5.96 \\
\hline Casearia decandra & 18 & 9 & 0.18 & 1.47 & 7 & 13 & 0.20 & 2.68 & 5 & 29 & 0.42 & 4.65 \\
\hline Lithraea brasiliensis & 4 & 36 & 1.51 & 5.63 & 5 & 22 & 1.05 & 5.06 & 6 & 17 & 1.13 & 3.69 \\
\hline Nectandra megapotamica & 9 & 14 & 0.42 & 2.27 & 8 & 12 & 0.43 & 2.66 & 7 & 20 & 0.69 & 3.37 \\
\hline Campomanesia xanthocarpa & 7 & 21 & 0.36 & 3.09 & 6 & 16 & 0.31 & 3.18 & 8 & 20 & 0.41 & 3.24 \\
\hline Ilex paraguariensis & 32 & 2 & 0.04 & 0.33 & 26 & 4 & 0.08 & 0.74 & 9 & 16 & 0.31 & 2.51 \\
\hline Cupania vernalis & 24 & 6 & 0.09 & 0.86 & 17 & 7 & 0.12 & 1.35 & 10 & 13 & 0.22 & 2.12 \\
\hline Other species & & 147 & 6.72 & 27.51 & & 108 & 4.90 & 26.90 & & 146 & 6.07 & 28.79 \\
\hline TOTAL & & 643 & 28.94 & 100 & & 444 & 20.36 & 100 & & 543 & 24.34 & 100 \\
\hline
\end{tabular}

$\mathrm{AD}=$ Absolute density (no. ind.ha $\left.{ }^{-1}\right) ; \mathrm{ADo}=$ Absolute dominance $\left(\mathrm{m}^{2} \cdot \mathrm{ha}^{-1}\right) ; \mathrm{P}=$ Position in the ranking of highest Importance Value Index; ()$=$ Time elapsed in relation to the selective logging interventions. 
Table 2. Absolute density, mean diameter, mean height, and basal area for Araucaria angustifolia for each measurement time and management treatment applied in the forest.

\begin{tabular}{|c|c|c|c|c|c|}
\hline \multirow{2}{*}{ Treatment } & \multirow{2}{*}{ Variable } & \multicolumn{4}{|c|}{ Time of measurement } \\
\hline & & 2001 & 2006 & 2010 & 2015 \\
\hline \multirow{4}{*}{$\begin{array}{c}\text { T0 } \\
\text { Control }\end{array}$} & No. ind.ha ${ }^{-1}$ & 22 & 21 & 21 & 21 \\
\hline & Mean DBH $(\mathrm{cm})$ & 48.3 & 51.1 & 52.1 & 53.6 \\
\hline & Mean height (m) & 19.0 & 19.6 & 20.1 & 20.6 \\
\hline & BA $\left(\mathrm{m}^{2} \cdot \mathrm{ha}^{-1}\right)$ & 4.34 & 4.56 & 4.73 & 5.02 \\
\hline \multirow{4}{*}{$\begin{array}{c}\mathrm{T} 1 \\
\text { Light selective logging }\end{array}$} & No. ind.ha $\mathrm{a}^{-1}$ & 17 & 24 & 29 & 41 \\
\hline & Mean DBH $(\mathrm{cm})$ & 34.9 & 31.3 & 29.9 & 27.2 \\
\hline & Mean height (m) & 18.5 & 16.0 & 15.5 & 15.0 \\
\hline & $\mathrm{BA}\left(\mathrm{m}^{2} \cdot \mathrm{ha}^{-1}\right)$ & 2.12 & 2.59 & 2.91 & 3.57 \\
\hline \multirow{4}{*}{$\begin{array}{c}\text { T2 } \\
\text { Moderate selective logging }\end{array}$} & No. ind.ha ${ }^{-1}$ & 23 & 23 & 24 & 30 \\
\hline & Mean DBH $(\mathrm{cm})$ & 35.9 & 38.4 & 38.9 & 35.1 \\
\hline & Mean height (m) & 19.3 & 18.8 & 18.4 & 17.4 \\
\hline & $\mathrm{BA}\left(\mathrm{m}^{2} \cdot \mathrm{ha}^{-1}\right)$ & 2.80 & 3.19 & 3.47 & 3.84 \\
\hline
\end{tabular}

$2001=1$ year prior to management intervention; 2006, 2010, $2015=4,8$, and 13 years after management intervention.

logging in both treatments, with absolute values of 12 ind.ha ${ }^{-1}$ and 6 ind.ha- ${ }^{-1}$ for T1 and T2, respectively. The recruitment of these smaller individuals contributed to reductions in the mean diameter and mean height variables in these management treatments 13 years after the selective logging interventions.

With respect to the control treatment (T0), higher absolute values were found for the basal area, mean diameter and mean height variables for all measurement times, suggesting that this forest fragment is in a more advanced stage of development owing to the absence of selective logging. Nevertheless, a deficit of 1 ind.ha ${ }^{-1}$ was verified in the analyzed period for this treatment, with no recruitment of araucaria trees. This finding reinforces the low potential of $A$. angustifolia individuals, present in the understory of highly dense forests, to develop and reach classes of adult vegetation $(\mathrm{DBH} \geq 10 \mathrm{~cm})$, being naturally substituted by the advance of broad-leaved species. This has already been referenced in several studies which reported the low regeneration capacity of araucaria under developed forest (Souza et al., 2008; Paludo et al., 2009; Callegaro \& Longhi, 2013; Beckert et al., 2014; Ebling et al., 2014).

The increase in $A$. angustifolia density in the management treatments ( $\mathrm{T} 1$ and $\mathrm{T} 2$ ) indicated that, regardless of selective logging intensity, canopy opening with reduction of competition for space, light, nutrients, etc. benefited the recruitment of individuals that were in the forest understory and presented sufficient growth $(\mathrm{DBH} \geq 10 \mathrm{~cm})$ to enter the forest growing stock. It is worth emphasizing that, due to A. angustifolia being a heliophic species when adult (Carvalho, 2003), and its benefitting from dim shading during germination and in the growing stage up to two years (Reitz \& Klein, 1966), lack of sunlight associated with thickening of the forest canopy and competition with the hardwood species prevent araucaria from finding favorable conditions for regeneration (Lingner et al., 2007), or even leading to individuals in the forest understory presenting stagnant growth, with small dimensions and susceptible to natural mortality if no sunlight is available.

One hypothesis for A. angustifolia distribution is the formation of demographic units by a group of trees recruited over the same time interval, constituting cohorts. According to Ogden \& Stewart (1995), current knowledge regarding the life history and mode of regeneration of forests with dominance of large conifers in the Southern Hemisphere was summarized in the conceptual model by Lozenge. According to this model, also known as "cohort structure", a group of conifers (cohort) of large size and demanding light (pioneers) establishes itself after severe disturbances. These groups are followed by cohorts of angiosperm (hardwood) species that dominate the forest understory and suppress the recruitment of conifers, which is restricted to the formation of clearings caused by the fall of trees. According to Souza (2007), if applicable for South American conifers, this model would characterize A. angustifolia as a pioneering, long-lived species with 
populations dominated by adults and dependent on disturbances for effective regeneration and long-term maintenance.

Higher recruitment rates of $A$. angustifolia have also been observed in areas with different exploitation histories. Sanquetta et al. (2003) analyzed growth, mortality and recruitment in two Forests with Araucaria in the state of Parana, and found higher A. angustifolia recruitment rates in an area that had undergone systematic understory thinning for yerba mate (Ilex paraguariensis) management and selective logging for timber, compared with that of another area that had been kept undisturbed for over 25 years, presenting low recruitment owing to high density forest and fiercer competition.

The growth of $A$. angustifolia trees observed in the present study evidenced the positive response of annual diameter increment (ADI) to the selective logging interventions, considering that both management treatments ( $\mathrm{T} 1$ and $\mathrm{T} 2$ ) presented higher values compared with those of the control treatment (T0), which obtained the smallest increments, with values of $0.25 \mathrm{~cm}$.year-1 in Period 1 (2006-2010) and $0.31 \mathrm{~cm}^{-y_{e} \text { yer }^{-1}}$ in Period 2 (2010-2015). The light selective logging treatment (T1) showed the highest rates of diameter growth, with values of $0.62 \mathrm{~cm}$.year ${ }^{-1}$ and $0.80 \mathrm{~cm}$.year ${ }^{-1}$ for Periods 1 and 2, respectively (Table 3 ).

The high diameter growth rate for A. angustifolia observed in $\mathrm{T} 1$ for the period between eight and 13 years after the management interventions is mostly attributed to the larger number of individuals recruited in the re-measurement of 2010 (eight years after the selective logging interventions), and presented a high growth rate due mainly to the favorable conditions that canopy opening provided to these individuals that were in the lower forest stratum. In a study on the growth dynamics of a Mixed Ombrophilous Forest, Beckert et al. (2014) verified mean annual diameter increment of $0.33 \mathrm{~cm}$.year- ${ }^{-1}$ for $A$. angustifolia, and concluded that the low increment rates were due to intense competition and little available sunlight in the lower forest strata. The authors also emphasize that the higher mortality rates compared with those of recruitment indicate a trend for this species to disappear if no silvicultural intervention is conducted.

Furthermore, when studying the remaining A. angustifolia trees in a 20-year-old logged forest area, Nogueira (1989) compared the radial increments prior to and after reaction to logging intervention for three types of canopy and clearly verified a large difference between them following reactions caused by logging. The radial increment was over twice as much as that found before the reaction for all types of canopy. The author also notes that this fact is the result of some treatment applied to the forest, attributed to canopy opening provided by selective logging, which significantly improved growth conditions, resulting in a greater diameter increment.

To compare the incremental rates between the treatments, verified by the relative annual diameter increment (ADI\%), after the Box-Cox transformation having indicated a lambda value $(\lambda)$ of zero within the

Table 3. Annual diameter increment for Araucaria angustifolia by management treatment.

\begin{tabular}{cccc}
\multirow{2}{*}{ Treatment } & Variable & \multicolumn{2}{c}{ Time of measurement } \\
\cline { 2 - 4 } & & $\mathbf{1}(\mathbf{2 0 0 6}-\mathbf{2 0 1 0})$ & $\mathbf{2 ( 2 0 1 0 - 2 0 1 5 )}$ \\
T0 & $\mathrm{N}$ & 21 & 21 \\
Control & $\mathrm{ADI}(\mathrm{cm})$ & 0.25 & 0.31 \\
& $\mathrm{ADI} \%$ & $0.52 \mathbf{~ b}$ & $0.60 \mathbf{b}$ \\
T1 & $\mathrm{N}$ & 24 & 29 \\
Light selective logging & $\mathrm{ADI}$ & 0.62 & 0.80 \\
& $\mathrm{ADI} \%$ & $3.14 \mathbf{a}$ & $4.03 \mathbf{a}$ \\
\hline T2 & $\mathrm{N}$ & 23 & 24 \\
\hline Moderate selective logging & $\mathrm{ADI}$ & 0.45 & 0.40 \\
\hline
\end{tabular}

$\mathrm{N}=$ number of observations; $\mathrm{ADI}=$ annual diameter increment; ADI\% = relative annual diameter increment; $(2006-2010)=$ Period between four and eight years after the selective logging interventions; $(2010-2015)=$ Period between eight and thirteen years after the selective logging interventions. Means followed by the same letter in the same column do not differ statistically by the Tukey-Kramer test, $\alpha=0.05$. 
confidence interval in both assessment periods, it was assumed that application of logarithmic transformation would be the best way to fit with the assumptions of ANOVA.

Table 3 shows that, in Period 1 (between four and eight years after the selective logging interventions), the mean relative diameter increment for A. angustifolia was higher for all selective logging treatments compared with those of the control treatment, presenting a statistically significant difference at $5 \%$ probability level. This result indicates that araucaria growth was positively influenced by the management interventions regardless of selective logging intensity.

As for Period 2 (between eight and 13 years after the selective logging interventions), it was possible to observe that the light selective logging treatment (T1) presented higher growth than the others, showing a statistically significant difference. This fact may be related to the significant recruitment of $A$. angustifolia in this treatment, therefore presenting a larger proportion of smaller individuals with increased growth potential. This behavior was observed to a lesser extent in the moderate selective logging treatment (T2), considering that the greatest recruitment occurred in 2015 and that these individuals were not included in the calculation of the mean increment rates.

In addition, reduction in competition and the consequent increase in availability of resources (sunlight, nutrients, etc.) that was provided to the remaining araucaria individuals contributed to the high diameter increment rates in the selective logging treatments (T1 and T2). Similarly, a study conducted by Nogueira (1989) reported that canopy opening, promoted by selective logging of the larger diameter araucarias, influenced the growth of the remaining trees, considering that reaction was observed in the radial growth of most trees.

According to Soares (1979), A. angustifolia is dependent on some level of disturbance to regenerate and remain dominant in its habitat. Based on what has been previously presented, this first management intervention at experimental level conducted in an MOF fragment located in the "Fazenda Tupi", municipality of Nova Prata, Rio Grande do Sul state, proved to be effective for both management intensities assessed. Nevertheless, light selective logging (reduction of approximately $20-30 \%$ in basal area) allowed for total recovery of the forest stock in a shorter time (less than 13 years), and it is therefore recommended as an alternative to reduce natural mortality (recruitment and increment) of A. angustifolia individuals present in forest understory and facing competition from broad-leaved species.

\section{CONCLUSIONS}

After thirteen years of application of different intensities of selective logging, it was possible to verify that the removal of hardwood species of low commercial value and high absolute density, mainly Matayba elaeagnoides - a common and dominant species in disturbed Forests with Araucaria - induce Araucaria angustifolia recruitment and growth in these environments. This finding reinforces that management of Mixed Ombrophilous Forests should be considered as a frequent and necessary practice for the perpetuation of Araucaria angustifolia in these stagnant forests which have undergone past disturbance.

\section{SUBMISSION STATUS}

Received: 15 dec., 2015

Accepted: 27 apr., 2017

\section{CORRESPONDENCE TO}

\section{Régis Villanova Longhi}

Departamento de Ciências Florestais, Centro de Ciências Rurais, Universidade Federal de Santa Maria - UFSM, Avenida Roraima, 1000, Camobi, CEP 97105-900, Santa Maria, RS, Brazil

e-mail: regislonghi@yahoo.com.br

\section{REFERENCES}

Alvares CA, Stape JL, Sentelhas PC, Gonçalves JLM, Sparovek G. Köppen's climate classification map for Brazil. Meteorologische Zeitschrift 2013; 22(6): 711-728. http:// dx.doi.org/10.1127/0941-2948/2013/0507.

Beckert SM, Rosot MAD, Rosot NC. Crescimento e dinâmica de Araucaria angustifolia (Bert.) O. Ktze. em fragmento de Floresta Ombrófila Mista. Scientia Forestalis 2014; 42(102): 209-218.

Borsoi GA. Subsídios para o manejo de uma Floresta Ombrófila Mista em estágio avançado de regeneração natural [thesis]. Santa Maria: Universidade Federal de Santa Maria; 2004 
Box GEP, Cox DR. An analysis of transformations. Journal of the Royal Statistical Society Series A 1964; 26(2): 211-252.

Brasil. Conselho Nacional do Meio Ambiente - CONAMA. Resoluções do CONAMA: resoluções vigentes publicadas entre setembro de 1984 e janeiro de 2012. Brasília: Ministério do Meio Ambiente; 2012. 1126 p.

Cabral DC, Cesco S. Notas para uma história da exploração madeireira na Mata Atlântica do sul-sudeste. Ambiente e Sociedade 2008; 11(1): 33-48. http://dx.doi.org/10.1590/ S1414-753X2008000100004.

Callegaro RM, Andrzejewski C, Longhi SJ, Longhi RV, Biali LJ. Composição das categorias sucessionais na estrutura horizontal, vertical e diamétrica de uma Floresta Ombrófila Mista Montana. Agrária 2016; 11(4): 350-358. http://dx.doi.org/10.5039/agraria.v11i4a5406.

Callegaro RM, Longhi SJ. Grupos florísticos em uma Floresta Ombrófila Mista, Nova Prata, RS, Brasil. Agrária 2013; 8(4): 641-647. http://dx.doi.org/10.5039/agraria. v8i4a2877.

Carvalho PER. Espécies florestais brasileiras: recomendações silviculturais, potencialidades e uso da madeira. Colombo: Embrapa; 1994.640 p.

Carvalho PER. Espécies arbóreas brasileiras. Brasília: Embrapa Informações Tecnológica; Colombo: Embrapa Florestas; 2003. (Coleção Espécies Arbóreas Brasileiras; no. 1).

Cordeiro JLP, Hasenack H. Cobertura vegetal atual do Rio Grande do Sul. In: Pillar VDP, Müller SC, Castilhos ZMS, Jacques AVA, editors. Campos sulinos: conservação e uso sustentável da biodiversidade. Brasília: Ministério do Meio Ambiente; 2009. 403 p.

Ebling AA, Guimarães PP, Pelissari AL, Abrão SF, Miranda ROV. Alterações florísticas e estruturais em floresta com araucária no estado do Rio Grande do Sul, Brasil. Agrarian Academy 2014; 1(1): 1-27. http://dx.doi.org/10.18677/ Agrarian_Academy_2014_002.

Guerra MP, Silveira V, Reis MS, Schneider L. Exploração, manejo e conservação da araucária (Araucaria angustifolia). In: Simões LL, Lino CF, editors. Sustentável Mata Atlântica: a exploração de seus recursos florestais. São Paulo: SENAC; 2002.

Higuchi P, Silva AC, Ferreira TS, Souza ST, Gomes JP, Silva KM et al. Influência de variáveis ambientais sobre o padrão estrutural e florístico do componente arbóreo, em um fragmento de Floresta Ombrófila Mista Montana em Lages, SC. Ciência Florestal 2012; 22(1): 79-90. http:// dx.doi.org/10.5902/198050985081.

Instituto Brasileiro de Geografia e Estatística - IBGE. Coordenação de Recursos Naturais e Estudos Ambientais. Manual técnico da vegetação brasileira. 2. ed. Rio de Janeiro; 2012. (Manuais Técnicos em Geociências).

Instituto Brasileiro do Meio Ambiente e dos Recursos Naturais Renováveis - IBAMA. Portaria $n^{\circ} 37-N$ de 3 de abril de 1992. Lista de espécies da flora ameaçadas de extinção. Diário Oficial da República Federativa do Brasil, Brasília, DF (1992 abr.).

Kanieski MR, Araujo ACB, Longhi SJ. Quantificação da diversidade em Floresta Ombrófila Mista por meio de diferentes Índices Alfa. Scientia Forestalis 2010; 38(88): 567-577.

Lingner DV, Oliveira YMM, Rosot NC, Dlugosz FL. Caracterização da estrutura e da dinâmica de um remanescente de Floresta com Araucária no Planalto Catarinense. Pesquisa Florestal Brasileira 2007; 55: 55-66.

Meyer HA. Structure, growth, and drain in balanced uneven-aged forests. Journal of Forestry 1952; 50: 85-92.

Mueller-Dombois D, Ellenberg H. Aims and methods in vegetation ecology. New York: Wiley; 1974.

Narvaes IS, Brena DA, Longhi SJ. Estrutura da regeneração natural em Floresta Ombrófila Mista na Floresta Nacional de São Francisco de Paula, RS. Ciência Florestal 2005; 15(4): 331-342. http://dx.doi.org/10.5902/198050981871.

Nogueira AC. Reação do crescimento radial da Araucaria angustifolia (Bert.) O. Ktze em florestas naturais que sofreram corte seletivo [thesis]. Curitiba: Universidade Federal do Paraná; 1989.

Nutto L. Manejo do crescimento diamétrico de Araucaria angustifolia (Bert.) O. Ktze. baseado na árvore individual. Ciência Florestal 2001; 11(2): 9-25. http://dx.doi. org/10.5902/198050981651.

Ogden J, Stewart GH. Community dynamics of the New Zealand conifers. In: Enright N, Hill RS, editors. Ecology of the Southern conifers. Washington: Smithsonian Institution Press; 1995.

Paludo GF, Mantovani A, Klauberg C, Reis MS.. Estrutura demográfica e padrão espacial de uma população natural de Araucaria angustifolia (Bertol.) Kuntze (Araucariaceae) em Santa Catarina. Revista Árvore 2009; 33(6): 1109-1121. http://dx.doi.org/10.1590/S0100-67622009000600013.

Reitz R, Klein RM. Araucariaceae. Itajaí: Herbário Barbosa Rodrigues; 1966. 29 p.

Reitz R, Klein RM, Reis A. Projeto Madeira do Rio Grande do Sul. Sellowia 1983; 34-35: 1-525.

Ribeiro MC, Metzger JP, Martensen AC, Ponzoni FJ, Hirota MM. The Brazilian Atlantic Forest: How much is left, and how is the remaining forest distributed? Implications for conservation. Biological Conservation 2009; 142(6): 1141 1153. http://dx.doi.org/10.1016/j.biocon.2009.02.021.

Rosot MAD. Manejo florestal de uso múltiplo: uma alternativa contra a extinção da Floresta com Araucária? Pesquisa Florestal Brasileira 2007; 55: 75-85.

Sanquetta CR, Dalla Côrte AP, Eisfeld RL. Crescimento, mortalidade e recrutamento em duas florestas de Araucária (Araucaria angustifolia (Bert.) O. Ktze.) no Estado do 
Paraná, Brasil. Revista Ciências Exatas e Naturais 2003; 5(1): 101-112.

Smith DM. The practice of silviculture. 8th ed. New York: John Wiley; 1986. 527 p.

Soares RV. Considerações sobre a regeneração natural da Araucaria angustifolia. Revista Floresta 1979; 10(2): 12-18.

Souza AF. Ecological interpretation of multiple population size structures in trees: the case of Araucaria angustifolia in South America. Austral Ecology 2007; 32(5): 524-533. http://dx.doi.org/10.1111/j.1442-9993.2007.01724.x.
Souza AF, Forgiarini C, Longhi SJ, Brena DA. Regeneration patterns of a long-lived dominant conifer and the effects of logging in southern South America. Acta Oecologica 2008; 34(2): 221-232. http://dx.doi.org/10.1016/j. actao.2008.05.013.

Streck EV, Kampf N, Dalmolin RSD, Klamt E, Nascimento PC, Schneider P. Solos do Rio Grande do Sul. 2. ed. Porto Alegre: Emater-RS/ASCAR; 2008.

Thomas P. Araucaria angustifolia. In: International Union for Conservation of Nature - IUCN. The IUCN Red List of Threatened Species. Switzerland; 2013. 